\title{
Prevention, diagnosis, and management of Japanese encephalitis in children
}

This article was published in the following Dove Press journal:

Pediatric Health, Medicine and Therapeutics

16 September 2014

Number of times this article has been viewed

\section{Rashmi Kumar \\ Department of Pediatrics, King George Medical University, Lucknow (UP), India}

Correspondence: Rashmi Kumar Department of Pediatrics, King George Medical University, Shahmina Road, Chowk, Lucknow (UP) 226003, India Tel +9l 94I5 408777

Email rashmik2005@gmail.com

\begin{abstract}
Japanese encephalitis is the single largest cause of viral encephalitis in the world today. It is caused by a Flavivirus whose natural cycle occurs in mosquito and vertebrate hosts (ardeid birds and pigs) and man is an incidental dead-end host. It tends to occur in outbreaks in poor rural regions of Asia where rice growing and pig rearing are a way of life. The illness has three stages - a prodromal stage with fever, headache, vomiting, and other nonspecific symptoms, an acute encephalitic stage with convulsions, coma, and signs of raised intracranial tension, and a convalescent stage. Differential diagnosis is very wide and even during epidemics it can be mimicked by many infectious and noninfectious disorders. The mainstay of laboratory diagnosis is the antibody capture enzyme-linked immunosorbent assay technique in cerebrospinal fluid. Treatment is essentially supportive and no antiviral has yet proven effective in randomized controlled trials. The mainstay of prevention is by vaccination. Many effective and safe vaccines are available and the IXIARO ${ }^{\circledR}$ vaccine - an inactivated vaccine from the SA-14-14-2 strain grown in vero cells - has received US Food and Drugs Administration approval. Japanese encephalitis control is thus a global health priority.
\end{abstract}

Keywords: JE vaccine, occurrence, natural cycle, acute encephalitis syndrome

\section{Introduction}

Japanese encephalitis (JE) known as the "plague of the Orient" is the commonest cause of epidemic viral encephalitis globally. ${ }^{1,2}$ About three billion people are estimated to live in JE endemic regions. Almost 45,000 cases of JE, with about 10,000 deaths and 15,000 survivors with neurodisabilities, are reported to the World Health Organization (WHO) each year, but this may be an underestimate due to inadequate surveillance systems and lack of viral diagnostic facilities in affected regions. ${ }^{3}$

\section{History, distribution, and occurrence}

$\mathrm{JE}$ is mainly a disease of the Asian continent. It was first recognized in Japan in 1924, ${ }^{4}$ and the virus was isolated from a fatal human case in 1935.,6 The next 70 years saw great expansion in the geographic areas affected by JE virus. The illness spread to the People's Republic of China, the eastern Soviet Union, South Korea, Vietnam, Malaysia, Indonesia, and Thailand in the 1960s. ${ }^{7}$ In India, the virus was first recognized from the south in $1955^{8,9}$ but the first epidemic occurred in 1973 in East-West Bengal. ${ }^{10}$ Since then it has firmly established in southern, eastern, and northeastern states of India while making inroads westwards. ${ }^{11-14}$ By the late 1970s, the first cases appeared in Bangladesh and Myanmar and large epidemics occurred in Nepal. ${ }^{15,16}$ Sri Lanka had its first epidemic in $1985 .{ }^{17} \mathrm{JE}$ continues to spread westwards and cases have been seen in Pakistan. ${ }^{18,19}$ 
It also spread downward to the Western Pacific islands, the Australian Torres Strait islands, and mainland Australia in the 1990s. ${ }^{20,21}$ Further east, it spread to the Philippines and New Guinea. Presently, JE occurs in 24 countries. ${ }^{22}$ The reason for the spread was probably the increase in rice irrigation and animal husbandry. ${ }^{23}$ In developed countries like Japan and Singapore, the number of cases has declined markedly. It is also steadily declining in the People's Republic of China and Korea. ${ }^{24,25}$ Local transmission has not been reported from Europe, Africa or the Americas. According to the Centers for Disease Control and Prevention, USA, JE occurs in less than one case per million travelers to Asia ${ }^{26}$ and from 1973 to 2001, only 58 cases of JE have been reported among travelers from non-endemic countries. ${ }^{27}$ Risk is likely to be higher if the period of stay in the endemic region is longer and if involved in outdoor activities in rural areas. ${ }^{28,29}$ Assuming an annual incidence of ten per 1,000 in the region being visited, the risk of developing the disease during a month long visit during the transmission season came to one per $5,000 .^{30}$

\section{The virus}

The JE virus (JEV) is a small, positive sense, single stranded RNA virus of the genus Flavivirus, family Flaviviridae. The term arbovirus or arthropod borne viruses is a descriptive ecologic term without taxonomic significance, meaning that the virus is transmitted by arthropods. JEV is closely related to other Flaviviruses including West Nile, Murray Valley encephalitis, and St Louis encephalitis viruses. The JE virion has a single strand of RNA wrapped in a nucleocapsid and surrounded by a glycoprotein containing envelope. ${ }^{31}$ There are three structural proteins - pre-membrane, core, and envelop $(E)$ and seven nonstructural proteins (NS1, NS2A, NS2B, NS3, NS4A, NS4B, NS5). The E protein is the largest structural protein with nearly 500 amino acids. It is considered important for the entry of a virus into host cells and is the main target for humoral immune response. ${ }^{31}$ There are five genotypes I to $\mathrm{V}$, based on the nucleotide sequence of the envelop $(E)$ gene. ${ }^{32-35}$ Genotype I and III were found mainly in northern temperate "epidemic" regions and genotypes II and IV were found in southern "endemic" regions. ${ }^{33,34,36} \mathrm{JEV}$ genotype V was first reported from Malaysia in 1952 (Muar strain) and reemerged after a 57-year hiatus in Asia (People's Republic of China) in 2009. ${ }^{35,37}$ Until 2007, all known Indian JEV strains belonged to genotype III. ${ }^{35,38-40}$ However, JEV genotype I has been introduced into the People's Republic of China, South Korea, and Thailand over the past decade ${ }^{41}$ and recently, genotype I has been isolated from the Gorakhpur region, India. ${ }^{42}$

\section{Life cycle}

The natural cycle of the JE virus explains the occurrence of the disease. JEV is transmitted in nature between the vector (mosquito) and the vertebrate host. The main vector in most of southeast Asia is the mosquito Culex tritaeniorrhynchus, a rice field breeding mosquito, but other vectors (C. vishnui, C. pseudovishnui, C. gelidus) also play a role. ${ }^{43}$ Birds of the family Ardeidae are thought to be important in maintaining, amplifying, and spreading the infection. Apart from birds, the pig is an important amplifying and "bridging" host as pigs are often kept close to human dwellings. This explains the occurrence principally in rural agricultural rice growing areas where pig rearing is common. ${ }^{44}$ Humans are accidental deadend hosts because the period of viremia in humans is too short to effectively transmit the infection further. Encephalitis does not occur in birds or pigs but abortion may occur in infected sows. Cattle also are not effective in transmitting the infection but may help support a large population of mosquitoes. Horses, like humans, may suffer encephalitis. ${ }^{43}$

\section{Epidemiology}

JE generally occurs in epidemics and outbreaks which coincide with periods of peak mosquito activity. It is primarily a disease of children and young adults, incidence being one to ten per 10,000 in affected areas. In temperate climates, transmission is seasonal, and usually peaks with summer epidemics. ${ }^{45}$ In tropical regions, transmission is endemic but occurs especially with monsoon rains. The ratio of apparent to unapparent infection varies from $1: 25$ to $1: 1,000$. Only one to two cases occur per village and some villages are completely spared. ${ }^{43}$ In endemic countries, adults acquire immunity through natural infection and JE is mainly a disease of children between 5 to 15 years of age. Adult infection tends to occur most commonly in areas where the infection is newly introduced. ${ }^{16,46}$ A study of 77 laboratory proven cases of the illness in children hospitalized during the 2005 epidemic in Uttar Pradesh, India revealed that almost all patients hailed from rural areas, children below two years of age were not affected, and boys accounted for almost $3 / 4$ of the cases. ${ }^{47}$

\section{Pathogenesis}

The spectrum of clinical features ranges from an undifferentiated flu-like illness to severe meningoencephalitis. The JEV E protein plays a major role in virulence phenotype and even single amino acid substitutions of this may cause loss of neuroinvasiveness. ${ }^{48,49}$ Changes in receptor binding site and hinge region E 52 and E 270-279 have been shown to result in loss of virulence. ${ }^{50}$ In addition, one more structural protein - the 
premembrane protein - contains glycosylation sites that showed protective potential. ${ }^{51}$ Among nonstructural proteins NS1 and NS3 are important ones that generate neurovirulence..$^{52,53}$

After entering the body through a mosquito bite, the virus multiplies within host leukocytes (probably T lymphocytes), and is carried to the central nervous system. The JEV virions bind to the endothelial surface of the brain blood vessels and are internalized by endocytosis. ${ }^{54}$ West Nile virus has been shown to enter the nervous system through antegrade axonal transport but it is not yet clear whether a similar spread occurs with JEV. ${ }^{55}$ Damage in flaviviral encephalitis appears to result both from direct virally mediated damage as well as host inflammatory response. Microglial cells undergo uncontrolled overactivation, ${ }^{56}$ releasing proinflammatory cytokines such as tumour necrosis factor alpha (TNFa), Monocyte Chemotactic Protein 1, interleukin 6 (IL-6), and RANTES (regulated upon activation, normal T cell expressed and secreted). This promotes massive leukocyte migration and infiltration in the brain. ${ }^{57}$ Besides neurons, astrocytes have also been shown to be infected with JEV. These cells release interferon $\gamma$ inducible protein 10 (IP-10) which also contributes to leukocyte infiltration. ${ }^{54}$ Nitric oxide is a strong antimicrobial agent and may play a role in host innate immunity. ${ }^{58}$ There is also evidence that JEV suppresses the proliferation of neuronal progenitor cells which may result in neurological sequelae..$^{59}$

\section{Effect of co-existing Flaviviruses}

Many JE endemic areas are also endemic for other Flaviviruses like dengue. ${ }^{60}$ There is cross-reaction between Flaviviral antibodies. ${ }^{61,62}$ There is evidence that the presence of prior dengue antibodies may protect against severe JE disease with lower mortality and severe sequelae. ${ }^{63}$ This phenomenon may explain the fact that younger children have worse outcomes as they may not have preexisting Flaviviral antibodies. ${ }^{64}$ On the other hand, prior infection with another serotype of dengue virus results in "immune enhancement" leading to severe manifestations of dengue like dengue hemorrhagic fever. This is because the antibodies to different serotypes are cross-reacting but not cross-neutralizing. ${ }^{65}$

\section{Pathology}

Although changes also occur in the lungs, myocardium, and reticuloendothelial system, the brain bears the brunt of the infection. There is swelling and intense congestion of the gray matter with confluent areas of hemorrhage. ${ }^{66} \mathrm{~A}$ characteristic finding is of focal, punched out areas of necrosis in the gray matter, but this is not pathognomonic. Infiltration of meninges and perivascular areas with mononuclear cells is seen. The cerebral cortex shows microglial infiltration with circumvascular necrolytic zones with total loss of neurons, whereas the white matter is fairly well preserved. ${ }^{67}$ Recently, apoptosis has been shown in vitro in different cell lines for various arboviruses. ${ }^{31}$

\section{Clinical features}

Infection with the JE virus can be asymptomatic, or present with an acute undifferentiated febrile illness, an aseptic meningitis like illness, an abortive encephalitis, or a full-fledged encephalitis-like illness. ${ }^{31}$ Incubation period is 5-15 days. When the course is one of encephalitis, the illness can be divided into three stages - prodromal, acute encephalitic, and a convalescent stage. The affliction starts abruptly with high fever. Headache, vomiting, and diarrhea may occur. Typically, this is followed in a matter of hours to a few days by seizures, usually generalized tonic spasms, following which the child lapses into coma. In severe cases, hyperventilation, signs of raised intracranial tension, shock, and death may occur in quick succession. Gastric hemorrhage is a common terminal event in seriously ill children. ${ }^{47}$ Focal deficits may occur in the form of hemiplegias, monoplegias, or even triplegias without corresponding lesions seen on imaging. The illness thus often has a compact clinical course and a patient may die before or just after reaching a health facility. About a third of children succumb during the acute stage of the infection, a third recover quickly within a few days, while the remainder have a prolonged convalescence. During the prolonged convalescence, pronounced extrapyramidal signs and focal deficits may become apparent. Severe dystonia and abnormal movements (head nodding, lip smacking, facial grimacing, pill-rolling movements, or choreoathetosis) may occur during the convalescent stage, gradually improving over a period of weeks to months. ${ }^{47}$

Clinical features of JE which can help to differentiate it from other acute meningoencephalitides have been studied by comparing with logistic regression, clinical features of laboratory confirmed cases with those in whom the diagnosis was excluded due to complete absence of antibodies. Two clinical signs, namely hyperventilation in the acute stage and extrapyramidal features, were significantly and independently associated with a diagnosis of JE. ${ }^{6}$

$\mathrm{JE}$ is now also recognized to involve spinal cord anterior horn cells and occasionally present with lower motor neurone polio-like weakness with atrophy. ${ }^{69,70}$ The polio-like illness may occur with a normal level of consciousness or with coma. ${ }^{70}$ 
A neutrophil leukocytosis is seen in the peripheral blood in most cases. Cerebrospinal fluid (CSF) examination may reveal a normal cell count or mild to moderate pleocytosis with elevated protein but normal sugar. During the JE epidemic of 2005, half the children seen in Lucknow had normal CSF and in the remainder there was a mild pleocytosis. Maximum CSF cell count was $300 / \mathrm{cubic}(\mathrm{cu}) \mathrm{mm}$ and only $12.3 \%$ of patients had counts beyond $100 / \mathrm{cu} \mathrm{mm} .{ }^{47}$

Neuroimaging studies in JE reveal hypodensities in the thalamus, basal ganglia, and brain stem. A study comparing a cranial computerized scan with magnetic resonance imaging found that $21 / 38(55.3 \%)$ patients showed abnormalities on the cranial computerized scan while magnetic resonance imaging was abnormal in all. ${ }^{71}$

Electrophysiological studies revealed electroencephalogram abnormalities in $80 \%$, in the form of nonspecific $\theta-\delta$ slowing, $\alpha$ coma, periodic lateralized epileptiform discharges, other epileptiform discharges, or burst suppression. Muscle evoked potentials were abnormal in $70 \%$, correlating with weakness and poor 3 month outcome. Electromyograms and somatosensory evoked potentials also revealed abnormalities in a small proportion of patients. ${ }^{72}$

\section{Differential diagnosis}

A clinical diagnosis of JE is usually made on the basis of clinical features consistent with encephalitis occurring in the context of an epidemic or outbreak in rural areas in monsoon and post-monsoon season in an endemic area. However, even during epidemics, the illness can be mimicked by a large variety of infectious and noninfectious disorders which can cause acute febrile encephalopathy (Table 1).

\section{Laboratory diagnosis}

Serological tests for JE include the neutralization test, agar gel diffusion test, single radial hemolysis, complement fixation test, and the hemagglutination inhibition test. ${ }^{73}$ Because of cross-reactivity among Flaviviruses such as West Nile and dengue, these tests should be performed along with other circulating Flaviviruses. These tests should be done in paired sera, acute and convalescent taken 14 days apart, and a four-fold rise or fall in titer to JEV without a similar rise in other Flaviviruses is suggestive of recent JEV infection. Until the 1990s, a hemagglutination inhibition test in paired sera was commonly used for diagnosis. However, the mainstay for diagnosis now is the Immunoglobulin M (IgM) capture enzyme-linked immunosorbent assay test in CSF or serum. Sensitivity as well as specificity of the test is higher in CSF making it the preferred sample. Detection of IgM in CSF is about $70 \%$ in the first week and about $95 \%$ after 10 days from onset of illness. If the initial sample (especially serum) was taken very early in the illness and tested negative for JEV IgM, it should preferably be repeated in serum after an interval of 7-10 days if the diagnostic suspicion is strong. ${ }^{74}$ There are three kits available commercially - the Excyton kit developed by the National Institute of Mental Health and Neurosciences, (Bangalore, India), the Inbios kit for JE (InBios International Inc., Seattle, Washington, USA) and a combo kit for dengue and JE marketed by PanBio, Brisbane, Australia. ${ }^{75-77}$ A comparative study of these kits revealed that sensitivity of all three was comparable but the PanBio kit had the highest specificity. Specificity of the Excyton kit was higher if dengue was excluded or only encephalitis cases were tested. ${ }^{78}$ Another kit (NIV kit for JEV IgM) has been developed by the National Institute of Virology, Pune and is widely used in the Integrated Disease Surveillance Program in India.

Attempts at isolating the virus from blood are mostly unsuccessful due to the very short period of viremia. It can occasionally be isolated from brain tissue obtained at autopsy or postmortem needle biopsy or from CSF. ${ }^{79}$

Detection of JEV genome by reverse transcriptase polymerase chain reaction techniques is being employed in the diagnosis of JE. The test is likely to be positive only in the early stages of the infection when serology may be noncontributory. However, polymerase chain reaction techniques are not very sensitive and viral genome may not be detectable in clinically ill JE patients. Therefore a positive test complements the serology but a negative result should not rule out JE. ${ }^{80-83}$

\section{Samples}

Blood (serum) and CSF specimens should be collected for JE diagnosis. For isolation of the virus, samples should be collected within 4 days after the onset of illness. For IgM detection, samples should be collected at least 5 days after the onset of illness.

Blood should be kept at room temperature until there is complete retraction of the clot from the serum. Thereafter the serum is separated aseptically and stored at $4^{\circ} \mathrm{C}-8^{\circ} \mathrm{C}$ until transportation to the laboratory. Alternatively, whole blood can be stored at $4^{\circ} \mathrm{C}-8^{\circ} \mathrm{C}$ for up to 24 hours but should not be frozen. The specimen can be transported in ice to the laboratory within 24 hours.

All attempts should be made to collect CSF samples for confirmation of diagnosis. CSF specimens should be collected aseptically in a sterile screw capped bottle and placed at $4^{\circ} \mathrm{C}$ as soon as possible. ${ }^{84}$ 
Table I Causes of acute febrile encephalopathy

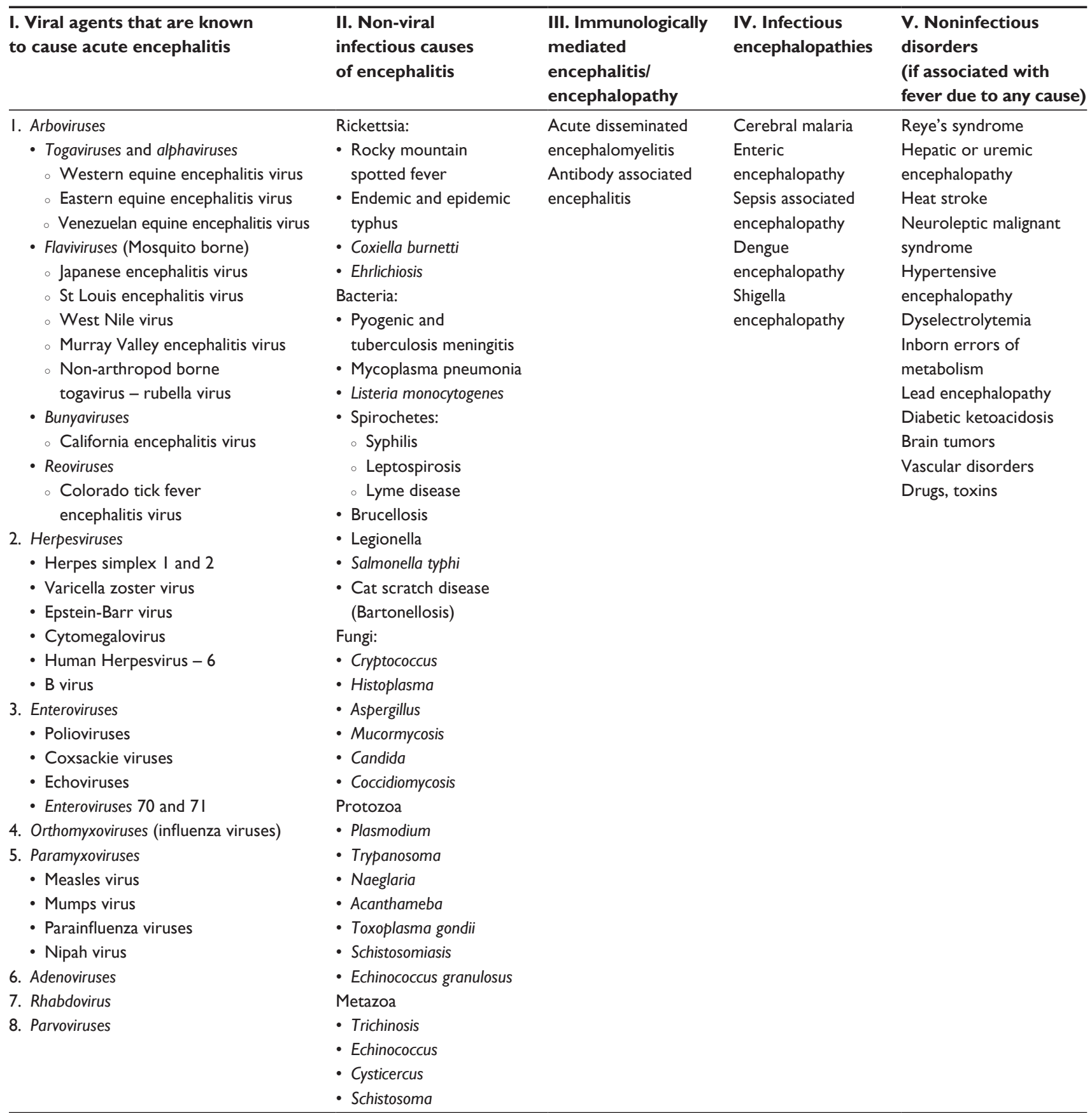

CSF and serum samples should be transported on wet ice, a thermos flask, or in an ice box to the designated laboratory as soon as possible. For both serum and CSF, if testing is likely to be delayed beyond 1 week, the sample can be stored frozen at $-20^{\circ} \mathrm{C}$ but repeated freezing and thawing is undesirable as it results in denaturation of antibody.

A second, convalescent serum sample should be collected 10-14 days after the first sample for IgM detection. The time since onset of illness should be mentioned on the sample. $^{84}$

\section{WHO case definition}

In 2006, recognizing the public health proportions of Japanese encephalitis in endemic regions, WHO coined the term acute encephalitis syndrome (AES) for surveillance purposes.

Clinically, AES is defined as:

a person of any age, at any time of year with acute onset of fever and at least one of ; a) change in mental status (including symptoms such as confusion, disorientation, coma, or 
inability to talk); b) new onset of seizures (excluding simple febrile seizures). Other early clinical findings may include an increase in irritability, somnolence or abnormal behavior greater than that seen with usual febrile illness. ${ }^{85}$

\section{Case classification}

According to WHO:

AES: a case that meets the clinical case definition of AES above. AES cases should be classified in one of the following 4 ways:

Laboratory Confirmed JE: An AES case that has been laboratory confirmed as JE.

Probable JE: An AES case that occurs in close geographical and temporal relationship to a laboratory confirmed case of JE, in the context of an outbreak.

AES - other agent: An AES case in which diagnostic testing is performed and an etiologic agent other than JE virus is identified.

AES - unknown: An AES case in which no diagnostic testing is performed or in which testing was performed but no etiologic agent was identified or in which test results were indeterminate.

The WHO has laid down criteria for laboratory confirmation of JE (Table 2) ${ }^{74}$ and also surveillance standards for JE (Table 3$).^{85}$

\section{Treatment}

To date, treatment of JE is essentially supportive. A severe case should be managed in an intensive care unit. Supportive measures include maintenance of airways, breathing and circulation, hydration, electrolyte status, and control of pyrexia and convulsions. It is prudent to use appropriate parenteral antibiotics to cover for bacterial infection. Raised intracranial tension should be controlled with mannitol infusion ( 0.25 to $1.0 \mathrm{gm} / \mathrm{kg}$ every 4-6 hours), intravenous furosemide or intermittent positive pressure ventilation to keep arterial carbon dioxide tension between $25-30 \mathrm{mmHg}$. Proper nursing care is of paramount importance to prevent aspiration pneumonia and bedsores. Adequate nutrition must be maintained to prevent malnutrition. The role of steroids in acute viral encephalitis is debatable. Theoretical arguments exist for and against their use. A study that evaluated high dose dexamethasone in JE found no benefit of steroid therapy. ${ }^{86}$

Randomized controlled trials with antivirals interferon alfa $^{87}$ and nasogastric ribavirin ${ }^{88}$ did not yield benefit. Minocycline, a tetracycline drug with antibacterial and neuroprotective properties, has recently been shown to be effective against the JE virus in an animal model. ${ }^{89}$

\section{Sequelae}

Clinical sequelae are seen in the majority of the survivors of JE. A study on 55 children, all laboratory proven cases

Table 2 WHO recommendation on JE laboratory diagnosis

\section{Laboratory criteria for confirmation}

Clinical signs of JE are indistinguishable from other causes of AES. Laboratory confirmation is therefore essential for accurate diagnosis of JE.

Laboratory confirmation of a JE virus infection includes:

I. Presence of JE virus-specific IgM antibody in a single sample of CSF or serum as detected by an IgM-capture ELISA specifically for JE virus; or any of the following:

2. Detection of JE virus antigens in tissue by immunohistochemistry; OR

3. Detection of JE virus genome in serum, plasma, blood, CSF, or tissue by reverse transcriptase polymerase chain reaction or an equally sensitive and specific nucleic acid amplification test; OR

4. Isolation of JE virus in serum, plasma, blood, CSF, or tissue; OR

5. Detection of a four-fold or greater rise in JE virus-specific antibody as measured by hemagglutination inhibition or plaque reduction neutralization assay in serum collected during the acute and convalescent phase of illness. The two specimens for lgG should be collected at least 14 days apart.

The IgG test should be performed in parallel with other confirmatory tests to eliminate the possibility of cross-reactivity, as indicated in the notes.

\section{Notes}

I. Because it may not yet be positive in a JE-infected person, a second serum sample should be collected at discharge or on the I0th day of illness onset or at the time of death and tested for presence of JE virus specific IgM.

2. Further confirmatory tests (eg, looking for cross-reactivity with other Flaviviruses circulating in the geographical area) should be carried out: (a) when there is an ongoing dengue or other Flavivirus outbreak; (b) when vaccination coverage is very high; or (c) in cases in areas where there are no epidemiological and entomological data supportive of JE transmission.

3. The large majority of JE infections are asymptomatic. Therefore, in areas that are highly endemic for JE, it is possible to have AES due to a cause other than JE virus and have JE virus-specific IgM antibody present in serum. To avoid implicating asymptomatic JE as the cause of other AES illnesses, sterile collection and testing of a CSF sample from all persons with AES are recommended when feasible.

4. Only the first 5-10 JE cases of an outbreak need be confirmed through laboratory testing. During periods of epidemic transmission of JE virus, laboratory confirmation of every case may not be necessary.

Note: Data from World Health Organization. Japanese Encephalitis Surveillance Standards. (From WHO-recommended standards for surveillance of selected vaccinepreventable diseases.) World Health Organization: 2006. ${ }^{85}$

Abbreviations: AES, acute encephalitis syndrome; CSF, cerebrospinal fluid; JE, Japanese encephalitis; WHO, World Health Organization; IgM, Immunoglobulin M; ELISA, enzyme-linked immunosorbent assay. 
Table 3 WHO criteria for JE surveillance

\section{Recommended types of surveillance}

JE surveillance should be conducted year round. Where feasible, surveillance for and reporting of JE should be performed within the context of integrated disease surveillance, and linked synergistically with similar surveillance activities, such as those for acute flaccid paralysis or meningitis.

In all Asian countries:

Comprehensive syndromic surveillance for acute encephalitis syndrome with aggregate reporting is recommended. In sentinel hospitals, surveillance should be case-based with specimens collected for laboratory confirmation. The number of sentinel hospitals can be gradually increased if feasible logistically.

In Asian countries where a high level of JE control has been achieved:

Surveillance should be case-based throughout the country and include laboratory confirmation of all suspect cases.

Notes: Regardless of the type of surveillance, reporting should be weekly or monthly and include "zero-reporting" (ie, no blanks should be left in the reporting forms, a zero should be indicated when there are no cases detected). Outbreak investigations should be initiated if there is a sudden increase in cases or if cases reported are different from historical information, in terms of season, geographical area, age group, or case fatality. Data from World Health Organization. Japanese Encephalitis Surveillance Standards. (From WHO-recommended standards for surveillance of selected vaccine-preventable diseases.) World Health Organization: $2006{ }^{85}$

Abbreviations: JE, Japanese encephalitis; WHO, World Health Organization.

followed up for periods ranging from 18 to 40 months, showed major sequelae in the form of obvious intellectual disability, obvious motor deficits, or epilepsy in $45.5 \%$. Scholastic backwardness, subtle neurologic signs, or behavioral abnormalities were found in another $25 \%$ and only $29 \%$ were completely normal. ${ }^{90}$

\section{Prevention}

Measures to prevent JE can be directed against: 1) the vector; 2) the vertebrate host; and 3) protection of the human host.

1. Anti-mosquito measures

Vector control for JE is expensive and is of limited efficacy in most settings. At best it can be used as a short-term measure to arrest an outbreak. However, emerging insecticide resistance of $C$. tritaeniorrhynchus has made even this less effective. Recent studies have shown a high level of resistance to organophosphorus compounds but susceptibility to pyrethroids. ${ }^{18}$ Application of larvicides to rice fields is another approach. The natural insecticide "neem" applied to rice fields may be a more eco-friendly approach, as may be placing larvivorous fish in rice paddies. Insecticide-treated mosquito nets have been used to study the effect on JEV seroconversion in pigs and humans in Assam, Northeast India. A sharp reduction of seroconversion rate in humans and pigs was found in treated localities after intervention. Cattle are dead-end hosts for JEV, so one approach may be to use cattle to divert mosquitoes away from swine and humans (zooprophylaxis). On the other hand, cattle support a large population of mosquitoes. Long-term anti-mosquito measures include better water management in rural areas, intermittent irrigation of rice paddies to disrupt mosquito breeding without impairing rice yield may prove an alternative strategy, and effective personal protection against mosquito bites including use of bed nets, insect repellants, and protective clothing. ${ }^{18}$

\section{Measures against the vertebrate host}

This includes control of the pig population in proximity to humans, by having piggeries away from human dwellings, and vaccination of pigs.

3. Protection of the human host

Human vaccination remains the most effective short-term strategy to control JE, the remaining measures being related to development, lifestyle, and alleviation of poverty. It must be borne in mind that the vaccination of humans does not interrupt JE transmission in nature. The reservoir of infection remains and unvaccinated individuals would be susceptible to the disease. Therefore high immunization rates must be maintained for effective long-term control. ${ }^{1}$ Nevertheless, JE control is feasible. Countries like Japan, the People's Republic of China, and Korea have had JE immunization programs in place for the last several decades. Others, such as India and Nepal, have also started JE vaccination, and Cambodia is planning the introduction of the JE vaccination soon. Many activities and collaborations concerning JE control were spearheaded by the Program for Appropriate Technology in Health JE project, with funding provided by the Bill and Melinda Gates Foundation. JE control is recognized to be an important measure for meeting the Millennium Development Goals and was supported by a 2005 World Health Assembly resolution on disability. Apart from the affected countries themselves, JE control has drawn many international stakeholders, including the WHO, the United States Centers for Disease Control and Prevention, the Armed Forces Research Institute of Medical Sciences, the International Vaccine Institute, vaccine manufacturers, and several universities. ${ }^{1}$

\section{Vaccines \\ Mouse brain killed vaccine}

The earliest vaccine to be marketed against JE was the inactivated vaccine derived from mouse brain originally produced 
by BIKEN (Kyoto, Japan) and marketed in the US as JE-VAX. Since the vaccine was derived from neural tissue, a risk of neurological events (acute disseminated encephalomyelitis) did exist. A new pattern of adverse reactions in the form of urticaria, angioedema, respiratory distress, and collapse due to hypotension has been reported since 1989, mostly among travelers vaccinated in Australia, Europe, and North America. Rates for these reactions varied from $0.7-104 / 1,000$. These safety concerns led to suspension of vaccine production and all remaining doses expired in $2011 .^{91}$

\section{P3 strain inactivated vaccine}

The cell culture-derived, formalin inactivated JE vaccine based on the Beijing P-3 strain is another vaccine in wide use in the Chengdu, People's Republic of China since the 1960s. Primary immunization of infants resulted in about 76\%-90\% protection, but immunity was relatively short-lived. The relatively low efficacy and need for repeated booster doses led to the vaccine being replaced by the live attenuated vaccine. ${ }^{91}$

\section{Live attenuated vaccine}

The only live attenuated JE vaccine currently available is the one derived from SA-14-14-2 strain, produced by Chengdu Biologicals (Chengdu TECBOND Biological Products Co, Ltd, Chengdu, People's Republic of China). ${ }^{92-95}$ This vaccine is being used in the public sector in the People's Republic of China (since 1998), Nepal (since 1999), and India (since 2006). Efficacy in a Nepalese study was $99.3 \%$ in the same year of vaccination, $98.5 \%$ after 1 year and $96.2 \%$ after 5 years. ${ }^{96-98}$ An Indian study found vaccine efficacy to be $94.5 \%$ after 6 months. ${ }^{99}$ Safety profile has been good with only $5 \%-10 \%$ of recipients developing transient fever, local reactions, rash, or irritability. This vaccine was imported by the government of India from the People's Republic of China after the Uttar Pradesh epidemic of 2005. The initial vaccine strain did not meet WHO prequalification standards but in July 2013, this vaccine, manufactured in the People's Republic of China in partnership with global health organization PATH, has received WHO prequalification status. ${ }^{100}$

\section{SA- I4- I4-2 strain inactivated vaccine}

The IC51 Vaccine - IXIARO ${ }^{\circledR}$ - manufactured by Intercell AG (Vienna, Austria) and distributed by Novartis Vaccines is a new generation formalin inactivated vaccine prepared from the SA-14-14-2 strain grown in vero cells. This is the only JE vaccine to have received US Food and Drug Administration approval for use in adults 17 years of age or older. This was accorded in March 2009 and the vaccine was later also approved in Europe and Australia. In May 2013, US Food and Drugs Administration approval for use also in children aged 2 months through 16 years was accorded. ${ }^{101}$ This vaccine, produced with Austrian collaboration, is available in India as JEEV (Biological E. Ltd., Hyderabad, India). ${ }^{102}$

There are no efficacy data for this vaccine. It was licensed in the US on the basis of its ability to induce neutralizing antibodies and also on safety evaluations in almost 5,000 adults. Among adults administered two primary doses of this vaccine 28 days apart, $96 \%$ developed protective neutralizing antibodies. $^{26}$

Local symptoms of pain and tenderness were the most commonly reported symptoms in a safety study with 1,993 adult participants who received two doses of IXI$\mathrm{ARO}^{\circledR}$. Headache, myalgia, fatigue, and an influenza-like illness were each reported at a rate of $>10 \%$. In children, fever was the most commonly reported systemic reaction. Because IXIARO ${ }^{\circledR}$ was licensed after study in about 5,000 recipients, the possibility of rare serious adverse events cannot be excluded. Post-licensure studies and surveillance are ongoing to further evaluate the safety of IXIARO ${ }^{\circledR}$ in a larger population. ${ }^{103,104}$

A severe allergic reaction after a previous dose of IXIARO $^{\circledR}$ is a contraindication to administration of further doses. IXIARO ${ }^{\circledR}$ contains protamine sulfate, a compound known to cause hypersensitivity reactions in some people. No studies of IXIARO ${ }^{\circledR}$ in pregnant women have been conducted. ${ }^{105}$

The full duration of protection after primary immunization with IXIARO ${ }^{\circledR}$ is unknown. ${ }^{106}$ The current recommended schedules of different vaccines is given in Table $4 .{ }^{103}$

IXIARO $^{\circledR}$ is the only vaccine which is US Food and Drug Administration approved for use in travelers. The Advisory Committee on Immunization Practices, USA recommends the JE vaccine:

... for travelers who plan to spend a month or more in endemic areas during the JE virus transmission season. This includes long-term travelers, recurrent travelers, or expatriates who will be based in urban areas but are likely to visit endemic rural or agricultural areas during a highrisk period of JE virus transmission. Vaccine should also be considered for (i) short-term ( $<1$ month) travelers to endemic areas during the JE virus transmission season, if they plan to travel outside an urban area and (ii) travelers to an area with an ongoing JE outbreak. ${ }^{105}$

The primary immunization schedule for IXIARO ${ }^{\circledR}$ is two doses administered intramuscularly on days 0 and 28. 
Table 4 Vaccines for Japanese encephalitis

\begin{tabular}{|c|c|c|c|}
\hline Vaccine & Dose & Schedule & Remarks \\
\hline Mouse brain killed vaccine & $\begin{array}{l}0.5 \mathrm{~mL} \text { for children age I to } 2 \text { years; } \\
1.0 \mathrm{~mL} \text { for children } 3 \text { years and older }\end{array}$ & $\begin{array}{l}2 \text { doses up to } 4 \text { weeks } \\
\text { apart }\end{array}$ & $\begin{array}{l}\text { Expensive } \\
\text { Short supply } \\
\text { Adverse effects } \\
\text { Production stopped }\end{array}$ \\
\hline P3 inactivated vaccine & $\begin{array}{l}0.5 \mathrm{~mL} \text { age } 6 \text { to } 12 \text { months, then boosters } \\
\text { at I year, school entry, and age } 10 \text { years }\end{array}$ & $\begin{array}{l}2 \text { doses }+ \text { booster every } \\
3 \text { years }\end{array}$ & $\begin{array}{l}\text { Low immunity } \\
\text { Need for boosters }\end{array}$ \\
\hline Live attenuated vaccine & $\begin{array}{l}0.25 \mathrm{~mL} \text { for } 2 \text { months through } 3 \text { years; } \\
0.5 \mathrm{~mL} \text { for } 3 \text { years of age and older }\end{array}$ & $\begin{array}{l}\text { Single dose } / 2 \text { doses I year } \\
\text { apart }\end{array}$ & $\begin{array}{l}\text { Good immunity even after } \\
5 \text { years } \\
\text { WHO prequalified in } 2013\end{array}$ \\
\hline IXIARO ${ }^{\circledR}$ & $\begin{array}{l}0.25 \mathrm{~mL} \text { for } 2 \text { months through } 2 \text { years; } \\
0.5 \mathrm{~mL} \text { for } 3 \text { years through } 16 \text { years } \\
\text { and } 0.5 \mathrm{~mL} \text { for } \geq 17 \text { years }\end{array}$ & $\begin{array}{l}2 \text { doses } 28 \text { days apart }+ \text { booster } \\
\text { after I year }\end{array}$ & $\begin{array}{l}\text { Full duration of protection after } \\
\text { primary immunization } \\
\text { is unknown }\end{array}$ \\
\hline Chimeric vaccine & & & Phase III trials underway \\
\hline
\end{tabular}

Note: IXIARO ${ }^{\circledR}$ manufactuerred by Novartis International AG, Basel, Switzerland.

Abbreviation: WHO, World Health Organizaton.

The two-dose series should be completed a week or more before travel.

Another vero cell-derived purified inactivated JE vaccine to have received manufacturing and marketing approval from the Drug Controller General of India is JENVAC. This vaccine was developed through public-private partnership between the Indian Council of Medical Research and Bharat Biotech Ltd. The virus strain (821564 XZ) used in this vaccine was isolated in Kolar, Karnataka, during the early 1980s and characterized by the National Institute of Virology, Pune. It is expected to meet the need for quick augmentation of immunity during an epidemic. ${ }^{107}$

\section{Chimeric vaccine}

Another JE vaccine being developed is the live attenuated YFV-17D/ JEV vaccine (Acambis, Cambridge, UK). In this vaccine, the pre-membrane and envelop genes of an attenuated human vaccine strain (SA-14-14-2) of JE virus were inserted between core and nonstructural genes of a YF 17D infectious clone, resulting in a live chimeric vaccine. Phase II trials have shown a seroconversion rate of $94 \%$ following a single shot. Recruitment for Phase III studies is ongoing in Thailand. ${ }^{91}$

\section{Conclusion}

$\mathrm{JE}$ is a disease which is still on the increase in many parts of Asia. It is a zoonosis with its natural cycle in pigs, birds, and mosquitos and man is an incidental dead-end host. It tends to occur in epidemics and outbreaks especially affecting poor rural rice growing, pig rearing people in Asia. The disease presents a severe encephalitis with compact clinical course, high mortality, and high disability rate in survivors. Diagnosis is usually made by presence of IgM antibody in CSF.
WHO guidelines for case definition and surveillance exist. Treatment to date is essentially supportive. The mainstay of prevention is by human vaccination. The main vaccines in use presently are the live attenuated SA-14-14-2 strain derived Chinese vaccine and the killed SA-14-14-2 strain derived vero cell vaccine. The latter is US Food and Drug Administration approved for travelers to endemic areas.

\section{Disclosure}

The author reports no conflicts of interest in this work.

\section{References}

1. Japanese Encephalitis Morbidity, Mortality, and Disability: Reduction and Control by 2015. PATH 2009. Available from: http://www.path. org/vaccineresources/files/JE_Reduction_and_Control_by_2015.pdf. Accessed July 11, 2014.

2. World Health Organization. Japanese encephalitis vaccines. Weekly Epidemiological Record. 2006;81(34/35):331-340.

3. World Health Organization. Weekly Epidemiological Record No 34/35. Relevé épidémiologique hebdomadaire; August 25, 2006. Available from: http://www.who.int/wer/2006/wer8134_35. pdf?ua=1:331. Accessed June 3, 2014.

4. Mackenzie JS, Williams DT, Smith DW. Japanese Encephalitis Virus: The Geographic Distribution, Incidence, and Spread of a Virus with a Propensity to Emerge in New Areas. In: Tabor E, editor. Emerging Viruses in Human Populations. Philadelphia: Elsevier; 2007;201-268.

5. Mitamura T, Kitaoka M, Watanabe M, et al. Study on Japanese encephalitis virus. Animal experiments and mosquito transmission experiments. Kansai Iji. 1936;1:260-261.

6. Lewis L, Taylor HG, Sorem MB, Norcross JW, Kindsvatter VH. Japanese B encephalitis: clinical observations in an outbreak on Okinawa Shima. Arch Neurol Psychiatry. 1947;57(4):430-463.

7. Erlanger TE, Weiss S, Keiser J, Utzinger J, Wiedenmayer K. Past, present, and future of Japanese encephalitis. Emerg Infect Dis. 2009;15(1). Available from: http://wwwnc.cdc.gov/eid/article/15/1/08-0311.htm. Accessed June 3, 2014.

8. Namachivayam V, Umayal K. Proceedings of the National Conference on Japanese Encephalitis. November 3-4 1982, New Delhi: Indian Council of Medical Research;1982:30-33.

9. Carey DE, Myers RM, Pavri KM. Japanese encephalitis studies in Vellore, South India. II. Antibody response of patients. Indian J Med Res. 1968;56(9):1319-1329. 
10. Sengupta SN, Sen M, Das PK, Bhattacharya DP. Epidemic of Japanese encephalitis in west Bengal: A clinical appraisal of the first 143 cases at Bankura. J Assoc Phys India. 1974;22:463-469.

11. Dhanda V, Thenmozhi V, Kumar NP, et al. Virus isolation from wildcaught mosquitoes during a Japanese encephalitis outbreak in Kerela in 1996. Indian J Med Res. 1997;106:4-6.

12. Mohanrao Rao CV, Prasad SR, Rodrigues JJ, Sharma NG, Shaikh BH, Pavri KM. The first laboratory proven outbreak of Japanese encephalitis in Goa. Indian J Med Res. 1983;78:745-750.

13. Prasad SR, Kumar V, Marwaha RK, Batra KL, Rath RK, Pal SR. An epidemic of encephalitis in Haryana: serological evidence of Japanese encephalitis in a few patients. Indian Pediatr. 1993;30(7):905-910.

14. Mathur A, Chaturvedi UC, Tandon HO, et al. Japanese encephalitis epidemic in Uttar Pradesh, India during 1978. Indian J Med Res. 1982;75:161-169.

15. Ministry of Health Nepal. Annual Report of the Department of Health Services. Katmandu (Nepal): Ministry of Health, Nepal; 2005.

16. Halstead SB. Arboviral encephalitis outside North America. In: Behrman RE, Kleigman RM, Jenson HB, editor. Nelson Textbook of Pediatrics. New Delhi: Elsevier;2004:1089-1091.

17. Abeysinghe MRN. Ministry of Healthcare, Nutrition and Uva Wellassa Development. Weekly Epidemiological Record of Sri Lanka. MoH Sri Lanka Weekly Epidemiological Report; 2005;32.

18. Solomon T. Japanese encephalitis vaccine. In: Jong EC, Zuckerman JN, editors. Travelers vaccines. Canada: B.C. Decker; 2004:219-256.

19. Igarashi A, Tanaka M, Morita K, et al. Detection of west Nile and Japanese encephalitis viral genome sequences in cerebrospinal fluid from acute encephalitis cases in Karachi, Pakistan. Microbiol and Immunol. 1994;38(10):827-830.

20. Mitchell CJ, Savage HM, Smith GC, Flood SP, Castro LT, Roppul M. Japanese encephalitis on Saipan: a survey of suspected mosquito vectors. Am J Trop Med Hyg. 1993;48(4):585-590.

21. Van Den Hurk AF, Montgomery BL, Northill JA, et al. Short report: the first isolation of Japanese encephalitis virus from mosquitoes collected from mainland Australia. Am J Trop Med Hyg. 2006;75(1): 21-25.

22. Campbell GL, Hills SL, Fischer M, et al. Estimated Global Incidence of Japanese Encephalitis: A Systematic Review. Bulletin of the World Health Organization; 2011. Available from: http:/www.who.int/bul letin/volumes/89/10/10-085233/en/. Accessed June 3, 2014.

23. Olson JG, Atmosoedjono S, Lee VH, Ksiazek TG. Correlation between population indices of Culex tritaeniorhynchus and $\mathrm{Cx}$. gelidus (Diptera: Culicidae) and rainfall in Kapuk, Indonesia. J Med Entomol. 1983;20(1):108-109.

24. Innis BL. Japanese encephalitis. In: Porterfield JS, editor. Exotic viral infections. London: Chapman and Hall; 1995:147-174.

25. Tsai TF, Chang J, Yu XX. Japanese encephalitis vaccines. In: Plotkin SA, Orenstein WA, editors. Vaccines. Philadelphia: WB Saunders; 1999:672-710.

26. Centers for Disease Control and Prevention. Japanese Encephalitis Vaccines. Recommendations of the Advisory Committee on Immunization Practices (ACIP). Morbidity and Mortality Weekly Report 2010; 59(No RR-01):1-27. Available from: http://www.cdc.gov/mmwr/ preview/mmwrhtml/rr5901a1.htm. Accessed June 3, 2014.

27. Hills SL, Griggs AC, Fischer M. Japanese encephalitis in travelers from non-endemic countries, 1973-2008. Am J Trop Med Hyg. 2010;82(5): 930-936.

28. Shlim D, Solomon T. Japanese encephalitis vaccine for travelers: exploring the limits of risk. Clin Infect Dis. 2002;35(2):183-188.

29. Hatz C, Werlein J, Mutsch M, Hufnagel M, Behrens RH. Japanese encephalitis: defining risk incidence for travelers to endemic countries and vaccine prescribing from the UK and Switzerland. J Trav Med. 2009;16(3):200-203.

30. Centers for Disease Control and Prevention. Inactivated Japanese encephalitis virus vaccine. Recommendations of the Advisory Committee on Immunization Practices (ACIP). MMWR Morb Mortal Wkly Rep. 1993;42:1-14.
31. Solomon T. Recent advances in Japanese encephalitis. J Neurovirology. 2003;9:274-283.

32. Hasegawa H, Yoshida M, Fujita S, Kobayashi Y. Comparison of structural proteins among antigenically different Japanese encephalitis virus strains. Vaccine. 1994;12(9):841-844.

33. Chen WR, Tesh RB, Rico-Hesse R. Genetic variation of Japanese encephalitis virus in nature. J Gen Virol. 1990;71:2915-2922.

34. Chen WR, Rico-Hesse R, Tesh RB. A new genotype of Japanese virus from Indonesia. Am J Trop Med Hyg. 1992;47(1):61-69.

35. Uchil PD, Satchidanandam V. Phylogenetic analysis of Japanese encephalitis virus: envelope gene based analysis reveals a fifth genotype, geographic clustering, and multiple introductions of the virus into the Indian subcontinent. Am J Trop Med Hyg. 2001;65(3):242-251.

36. Williams DT, Wang LF, Daniels PW, Mackenzie JS. Molecular characterization of the first Australian isolate of Japanese encephalitis virus, the FU strain. J Gen Virol. 2000;81:2471-2480.

37. Li MH, Fu SH, Chen WX, et al. Genotype v Japanese encephalitis virus is emerging. PLoS Negl Trop Dis. 2011;5(7):e1231.

38. Saxena SK, Mishra N, Saxena R, Singh M, Mathur A. Trend of Japanese encephalitis in north India: evidence from thirty-eight acute encephalitis cases and appraisal of niceties. J Infect Dev Ctries. 2009;30(7): 517-530.

39. Sapkal GN, Bondre VP, Fulmali PV, et al. Enteroviruses in patients with acute encephalitis, uttar pradesh, India. Emerg Infect Dis. 2009;15(2): 295-298.

40. Mackenzie JS, Gubler DJ, Petersen LR. Emerging flaviviruses: the spread and resurgence of Japanese encephalitis, West Nile and dengue viruses. Nat Med. 2004;10(Suppl 12):S98-S109.

41. Huang JH, Lin TH, Teng HJ, et al. Molecular epidemiology of Japanese encephalitis virus, Taiwan. Emerg Infect Dis. 2010;16(5):876-878.

42. Fulmali PV, Sapkal GN, Athawale S, Gore MM, Mishra AC, Bondre VP. Introduction of Japanese encephalitis virus genotype I, India. Emerg Infect Dis. 2011;17(2):319-321.

43. Medappa N. Japanese encephalitis. ICMR Bulletin. 1980;10:29-38.

44. Rosen L. The natural history of Japanese encephalitis virus. Annu Rev Microbiol. 1986;40:395-414.

45. Tirounourougane SV, Raghava P, Srinivasan S. Japanese viral encephalitis. Postgrad Med J. 2002;78:205-215.

46. Rayamajhi A, Singh R, Prasad R, Khanal B, Singhi S. Clinico-laboratory profile and outcome of Japanese encephalitis in Nepali children. Ann Trop Paediatr. 2006;26(4):293-301.

47. Kumar R, Tripathi P, Singh S, Bannerji G. Clinical features in children hospitalized during the 2005 epidemic of Japanese encephalitis in Uttar Pradesh, India. Clin Infect Dis. 2006;43(2):123-131.

48. Lin YL, Chen LK, Liao CL, et al. DNA immunization with Japanese encephalitis virus nonstructural protein NS1 elicits protective immunity in mice. J Virol. 1998;72(1):191-200.

49. Zhang Y, Chen P, Cao R, Gu J. Mutation of putative N-Linked glycosylation sites in Japanese encephalitis virus pre-membrane and envelope proteins enhances humoral immunity in BALB/C mice after DNA vaccination. Virol J. 2011;8:138.

50. Cecilia D, Gould EA. Nucleotide changes responsible for loss of neuroinvasiveness in Japanese encephalitis virus neutralization-resistant mutants. Virology. 1991;181(1):70-77.

51. Kim JM, Yun SI, Song BH, et al. A single N-linked glycosylation site in the Japanese encephalitis virus prM protein is critical for cell typespecific prM protein biogenesis, virus particle release, and pathogenicity in mice. J Virol. 2008;82(16):7846-7862.

52. Yamashita T, Unno H, Mori Y, et al. Crystal structure of the catalytic domain of Japanese encephalitis virus NS3 helicase/nucleoside triphosphatase at a resolution of $1.8 \AA$. Virology. 2008;373(2):426-436.

53. Gould EA, Buckley A, Barrett ADT, Cammack N. Neutralizing (54K) and non-neutralizing $(54 \mathrm{~K}$ and $48 \mathrm{~K})$ monoclonal antibodies against structural and non-structural yellow fever virus proteins confer immunity in mice. J Gen Virol. 1986;67(3):591-595.

54. Ghosh D, Basu A. Japanese encephalitis - a pathological and clinical perspective. PLoS Negl Trop Dis. 2009;3(9):e437. 
55. Hunsperger EA, Roehrig JT. Temporal analysis of the pathogenesis of a West Nile virus infection in mice. J Neurovirol. 2006;12(2): 129-139.

56. Ghoshal A, Das S, Ghosh S, et al. Proinflammatory mediators released by activated microglia induces neuronal death in Japanese encephalitis. Glia. 2007;55(5):483-496.

57. Chen CJ, Chen JH, Chen SY, Liao SL, Raung SL. Upregulation of RANTES gene expression in neuroglia by Japanese encephalitis virus infection. J Virol. 2004;78(22):12107-12119.

58. Lin YL, Huang YL, Ma SH, et al. Inhibition of Japanese encephalitis virus infection by nitric oxide: antiviral effect of nitric oxide on RNA virus replication. J Virol. 1997;71(7):5227-5235.

59. Das S, Basu A. Japanese encephalitis virus infects neural progenitor cells and decreases their proliferation. $J$ Neurochem. 2008;106(4): $1624-1636$.

60. Cardosa MJ, Wang SM, Sum MS, Tio PH. Antibodies against prM protein distinguish between previous infection with dengue and Japanese encephalitis viruses. BMC Microbiol. 2002;2:9.

61. Martin DA, Biggerstaff BJ, Allen B, Johnson AJ, Lanciotti RS, Roehrig JT. Use of immunoglobulin $\mathrm{m}$ cross-reactions in differential diagnosis of human flaviviral encephalitis infections in the United States. Clin Diagn Lab Immunol. 2002;9(3):544-549.

62. Makino Y, Tadano M, Saito M, et al. Studies on serological crossreaction in sequential flavivirus infections. Microbiol Immunol. 1994; 38(12):951-955.

63. Burke DS, Lorsomrudee W, Leake CJ, et al. Fatal outcome in Japanese encephalitis. Am J Trop Med Hyg. 1985;34(6):1203-1210.

64. Bosco-Lauth A, Mason G, Bowen R. Pathogenesis of Japanese encephalitis virus infection in a golden hamster model and evaluation of flavivirus cross protective immunity. Am J Trop Med Hyg. 2011;84(5): 727-732.

65. Lei HY, Yeh TM, Liu HS, Lin YS, Chen SH, Liu CC. Immunopathogenesis of Dengue Virus Infection. J Biomed Sci. 2001; $8: 377-388$.

66. Miyake M. The pathology of Japanese encephalitis. Bull World Health Organisation. 1964;30:153-160. Available from: http://whqlibdoc.who. int/bulletin/1964/Vol30/Vol30-No2/bulle tin_1964_30(2)_153-160.pdf. Accessed June 3, 2014.

67. Shankar SK, Rao TV, Mruthyunjayanna BP, Gourie Devi M, Deshpande DH. Autopsy study of brains during the epidemic of Japanese encephalitis in Karnataka. Indian J Med Res. 1983;78:431-440.

68. Kumar R, Selvan AS, Sharma S, et al. Clinical predictors of Japanese encephalitis. Neuroepidemiology. 1994;13:97-102.

69. Kumar R, Agarwal SP, Wakhlu I, Mishra KL. Japanese encephalitis an encephalomyelitis. Indian Pediatr. 1991;28:1525-1528.

70. Solomon T, Kneen R, Dung NM, et al. Poliomyelitis-like illness due to Japanese encephalitis virus. Lancet. 1998;351(9109):1094-1097.

71. Kumar S, Misra UK, Kalita J, Salwani V, Gupta RK, Gujral R. MRI in Japanese encephalitis. Am J Med Sci. 1997;39(3):180-184.

72. Kalita J, Misra UK. Neurophysiological changes in Japanese encephalitis. Neurol India. 2002;50(3):262-266.

73. Kumar R. Viral encephalitis of public health significance in India: current status. Indian J Pediatr. 1999;66(1):73-83.

74. World Health Organization. WHO Manual for the Laboratory Diagnosis of Japanese Encephalitis Virus Infection. 2007. Available from: http:// www.wpro.who.int/immunization/documents/Manual_lab_diagnosis_JE.pdf. Accessed June 3, 2014.

75. Ravi V, Desai A, Balaji M, et al. Development and evaluation of a rapid IgM capture ELISA (JEV-Chex) for the diagnosis of Japanese encephalitis. J Clin Virol. 2006;35(4):429-434.

76. Martin DA, Muth DA, Brown T, Johnson AJ, Karabatsos R, Roehrig JT. Standardization of immunoglobulin $M$ capture enzyme-linked immunosorbent assays for routine diagnosis of arboviral infections. J Clin Microbiol. 2000;38(5):1823-1826.

77. Innis BL, Nisalak A, Nimmannitya S, et al. An enzyme-linked immunosorbent assay to characterize dengue infections where dengue and Japanese encephalitis co-circulate. Am J Trop Med Hyg. 1989;40(4) $418-427$.
78. Jacobson JA, Hills SL, Winkler JL, et al. Evaluation of three immunoglobulin $\mathrm{M}$ antibody capture enzyme-linked immunosorbent assays for diagnosis of Japanese encephalitis. Am J Trop Med Hyg. 2007;77(1):164-168.

79. Solomon T, Dung NM, Kneen R, Gainsborough M, Vaughn DW, Khanh VT. Japanese encephalitis. J Neurol Neurosurg Psychiatry. 2000;68:405-415.

80. Swami R, Ratho RK, Mishra B, Singh MP. Usefulness of RT-PCR for the diagnosis of Japanese encephalitis in clinical samples. Scand $J$ Infect Dis. 2008;40(10):815-820.

81. Yang DK, Kweon $\mathrm{CH}$, Kim BH, et al. TaqMan reverse transcription polymerase chain reaction for the detection of Japanese encephalitis virus. J Vet Sci. 2004;5(4):345-351.

82. Patel P, Landt O, Kaiser M, et al. Development of one-step quantitative reverse transcription PCR for the rapid detection of flaviviruses. Virol J. 2013;10:58

83. Yeh JY, Lee JH, Seo HJ, et al. Fast duplex one-step reverse transcriptase PCR for rapid differential detection of West Nile and Japanese encephalitis viruses. J Clin Microbiol. 2010;48(11):4010-4014.

84. Government of India. Guidelines. Clinical Management of Acute Encephalitis Syndrome including Japanese Encephalitis. Directorate of National Vector Borne Diseases Control Programme. Delhi; 2009. Available from: http://www.nvbdcp.gov.in/Doc/Clinical\%20Management-JE. pdf. Accessed June 3, 2014.

85. World Health Organization. Japanese Encephalitis Surveillance Standards. (From WHO-recommended standards for surveillance of selected vaccine-preventable diseases.) World Health Organization: 2006. Available from: http://whqlibdoc.who.int/hq/2003/ who_v\&b_03.01.pdf. Accessed June 3, 2014.

86. Hoke CH Jr, Vaughn DW, Nisalak A, et al. Effect of high dose dexamethasone on the outcome of acute encephalitis due to Japanese encephalitis virus. $J$ Infect Dis. 1992;165(4):631-637.

87. Solomon T, Dung NM, Wills B, et al. Interferon alfa-2a in Japanese encephalitis: a randomised double-blind placebo-controlled trial. Lancet. 2003;361(9360):821-826.

88. Kumar R, Tripathi P, Barawal M, Singh S, Tripathi S, Banerji G. Randomized, controlled trial of oral ribavirin for Japanese encephalitis in children in Uttar Pradesh, India. Clin Infect Dis. 2009;48(4): 400-406.

89. Mishra MK, Basu A. Minocycline neuroprotects, reduces microglial activation, inhibits caspase 3 induction, and viral replication following Japanese encephalitis. J Neurochem. 2008;105(5):1582-1595.

90. Kumar R, Mathur A, Singh KB, et al. Clinical sequelae of Japanese encephalitis in children. Indian J Med Res. 1993;97:9-13.

91. WHO position paper on Japanese encephalitis vaccines, 2006. Weekly Epidemiological Record. 2006;81:325-340. Available from: http://www. who.int/wer/2006/wer8134_35.pdf. Accessed July 10, 2014.

92. Xin YY, Ming ZG, Peng GY, Jian A, Min LH. Safety of a live-attenuated Japanese encephalitis virus vaccine (SA14-14-2) for children. Am J Trop Med Hyg. 1988;39(2):214-217.

93. Hennessy S, Liu Z, Tsai TF, et al. Effectiveness of live-attenuated Japanese encephalitis vaccine (SA14-14-2): a case-control study. Lancet. 1996;347(9015):1583-1586.

94. World Health Organization. WHO Expert Committee on Biological Standardization. Geneva: World Health Organization Technical Report Series; 2002;910:1-104. Available from: http://www.who.int/ biologicals/publications/trs/51/en/index.html. Accessed June 3, 2014.

95. World Health Organisation. Global Advisory Committee on Vaccine Safety, June 9-10, 2005. Wkly Epidemiol Rec 2005;80:242-243. Available from: http://www.who.int/wer/2005/wer8028.pdf. Accessed June 3, 2014.

96. Bista MB, Banerjee MK, Shin SH, et al. Efficacy of single-dose SA 14-14-2 vaccine against Japanese encephalitis: a case control study. Lancet. 2001;358(9284):791-795.

97. Ohrr H, Tandan JB, Sohn YM, Shin SH, Pradhan DP, Halstead SB. Effect of single dose of SA 14-14-2 vaccine 1 year after immunisation in Nepalese children with Japanese encephalitis: a case-control study. Lancet. 2005;366(9494):1375-1378. 
98. Tandan JB, Ohrr H, Sohn YM, et al. Single dose of SA 14-14-2 vaccine provides long-term protection against Japanese encephalitis: a case-control study in Nepalese children 5 years after immunization. Vaccine. 2007;25(27):5041-5045.

99. Kumar R, Tripathi P, Rizvi A. Effectiveness of one dose of SA-14-14-2 vaccine against Japanese encephalitis. N Engl J Med. 2009;360(14): 1465-1466.

100. World Health Organization. Newly accessible Japanese encephalitis vaccine will make saving children easier in developing countries [news release]. Geneva: World Health Organization; 2013 [October 9]. Available from: http://www.who.int/mediacentre/news/releases/2013/ japanese_encephalitis_20131009/en/index.html. Accessed June 3, 2014.

101. Food and Drugs Administration. Highlights of Prescribing Information. Available from: http://www.fda.gov/downloads/BiologicsBlood Vaccines/Vaccines/ApprovedProducts/UCM142569.pdf. Accessed June 3, 2014.

102. Life Science Austria. Intercell's partner Biological E. Ltd launches Japanese Encephalitis vaccine JEEV ${ }^{\circledR}$ in India. 2012 [September 13]. Available from: http://www.lifescienceaustria.at/en/intercells-partnerbiological-e-ltd-launches-japanese-encephalitis-vaccine-jeev-inindia/. Accessed June 3, 2014.
103. Centers for Disease Control and Prevention. Infectious diseases related to travel. In: Hills SL, Weber IB, Fischer M. CDC Health Information for International Travel 2014: The Yellow Book. OUP USA: 2013. Available from: http://wwwnc.cdc.gov/travel/yellowbook/2014/ chapter-3-infectious-diseases-related-to-travel/japanese-encephalitis. Accessed June 3, 2014.

104. Schuller E, Klingler A, Dubischar-Kastner K, Dewasthaly S, Müller Z. Safety profile of the Vero cell-derived Japanese encephalitis virus (JEV) vaccine IXIARO $\left({ }^{\circledR}\right)$. Vaccine. 2011;29(47):8669-8676.

105. Centers for Disease Control and Prevention. Recommendations for use of a booster dose of inactivated vero cell culture-derived Japanese encephalitis vaccine: advisory committee on immunization practices, 2011. MMWR Morb Mortal Wkly Rep. 2011;60(20):661-663.

106. Fischer M, Lindsey N, Staples JE, Hills S, Centers for Disease Control and Prevention (CDC). Japanese encephalitis vaccines: recommendations of the Advisory Committee on Immunization Practices (ACIP). MMWR Recomm Rep. 2010;59(RR-1):1-27.

107. India launches vaccine to prevent Japanese encephalitis. The Hindu. October 4 2013. Available from: http://www.thehindu.com/news/ national/india-launches-vaccine-to-prevent-japanese-encephalitis/ article5201813.ece. Accessed June 3, 2014.

\section{Publish your work in this journal}

Pediatric Health, Medicine and Therapeutics is an international, peerreviewed, open access journal publishing original research, reports, editorials, reviews and commentaries. All aspects of health maintenance, preventative measures and disease treatment interventions are addressed within the journal. Practitioners from all disciplines are invited to submit

\section{Dovepress}

their work as well as healthcare researchers and patient support groups. The manuscript management system is completely online and includes a very quick and fair peer-review system. Visit http://www.dovepress.com/ testimonials.php to read real quotes from published authors. 